\title{
ТЕАТРАЛЬНЕ МИСТЕЦТВО МАРІУПОЛЯ: СТОРІНКИ ІСТОРІЇ ТА СУЧАСНІ РЕАЛІЇ
}

\author{
Любов Голубцова ${ }^{1 a}$, Сергій Плуталов ${ }^{2 a}$, Марина Мусієнко ${ }^{3 b}$ \\ ${ }^{1}$ кандидат мистецтвознавства, доцент; e-mail: golubtsova@i.ua; ORCID: 0000-0002-5807-2176 \\ ${ }^{2}$ магістр; e-mail: si.plutalovv@gmail.com; ORCID: 0000-0001-9155-5324 \\ ${ }^{3}$ магістр; e-mail: m.musienko0511@yandex.ua; ORCID: 0000-0002-8928-3785 \\ а Луганська державна академія культури і мистецтв, Київ, Україна

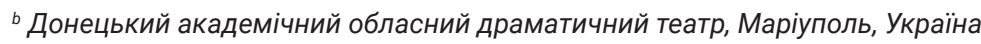

\section{Анотація}

Мета дослідження - розглянути історію виникнення сценічного мистецтва Маріуполя та схарактеризувати технології акторського мистецтва (традиційні й інноваційні), на які спирається у своїй діяльності колектив Маріупольського драматичного театру. Методологія дослідження. Для досягнення мети дослідження використано такі методи: історичний (для дослідження етапів становлення театрального мистецтва Донеччини); аналітичний (з метою виявлення основних принципів акторської школи як результату її історичної еволюції); культурологічний (для розгляду традицій акторської школи в контексті розвитку сучасного сценічного мистецтва Маріуполя); мистецтвознавчий (в аналізі акторської школи та форм режисерських технологій); джерелознавчі (у вивченні архівних матеріалів, пов'язаних з театральним життям міста). Наукова новизна полягає в тому, що виявлено специфіку сучасного акторського мистецтва Маріуполя та його зв'язки зі здобутками класичного українського театру корифеїв. Висновки. Осередком театральної культури Донеччини є Донецький академічний обласний драматичний театр (м. Маріуполь). Аналіз діяльності театру на різних етапах його функціонування дає змогу стверджувати, що історичні реалії розвитку акторської школи корифеїв на Донеччині мають фрагментарне висвітлення в історико-культурологічній, мистецтвознавчій і театрознавчій літературі; формування репертуарних уподобань в акторських трупах відбувалося під впливом гастрольної діяльності театру корифеїв. Особливу роль у цьому процесі відігравали принципи роботи над художніми образами як центральним елементом вистави, який ії композиційно об'єднує та опосередковано впливає на інші складники. Незважаючи на період так званого «застою», у радянських театральних практиках наприкінці 70-х років простежуємо тенденції повернення до традиційних для українського театру форм сценічної виразності, що сприяло активізації режисерської й акторської творчості в пошуку нових варіантів поєднання театральних засобів української побутової драми з іншими, притаманними класичному та сучасному європейському театру драми та комедії. Основні риси української акторської школи Маріупольського театру: реалістичний підхід до створення сценічних образів; широке використання музики, співу, танцю; плідна робота актора над собою.

Ключові слова: сценічне мистецтво Маріуполя; акторське мистецтво; традиції театру корифеїв 


\section{Постановка проблеми}

Сучасні дослідження свідчать про наявність різних підходів вивчення традицій корифеїв українського театру. Більшість науковців визнає безумовний вплив акторської школи корифеїв на формування сучасного українського театру. Відомі роботи, присвячені аналізу творчості видатних акторів українського театру кінця XIX - початку XX ст., у яких розкрито своєрідність сценічного мистецтва корифеїв, завдяки яким відбулися кардинальні зміни в розвитку сценічного мистецтва України.

Попри те, що окремі аспекти аналізу традицій акторської школи корифеїв наведено в працях багатьох науковців, усе ж немає комплексного дослідження, яке розкрило б зміст питання, чи мають продовження ці традиції у сучасних виставах.

\section{Аналіз останніх досліджень і публікацій}

Джерельною базою є широке коло досліджень, які у різних виявах представлені в науковому обігу.

Історію становлення традицій акторської школи, що вплинули на формування українського театру, подано в роботах таких авторів, як Д. Антонович (2003), Р. Єсипенко (1994), В. Заболотна (2006), О. Кисіль (1925), І. Мар'яненко (1954), А. Новіков (2000) та ін. Розгляд творчості видатних акторів театру корифеїв висвітлено також у дослідженнях сучасних науковців, зокрема С. Гордєєва (2003), В. Заболотної (2006), С. Дуриліна (1982), Т. Кінзерської (2002), Н. Малюшицької (2002), С. Тобілевич (1947) та ін.

Д. Антонович $(2003$, с. 142$)$ наголошував на необхідності вивчення «практичної школи» М. Кропивницького, через яку пройшло декілька поколінь українських акторів. Дослідник, вивчаючи історію українського театру, зауважує, що «...власне, всі трупи і всі актори українського побутового театру - це актори школи Кропивницького [...] Це все або учні Кропивницького, або учні учнів Кропивницького, але всі - одна його школа...» (2003, с. 159).

Цікавий висновок наведено і в праці історика українського театру О. Кисіля (1925, с.96-97), який розглядав еволюцію сценічної творчості плеяди корифеїв та підкреслював, що вона утвердила школу, з якої запозичили зразки блискучої сценічної гри наступні покоління українських акторів.

Р. Єсипенко (1994) у своїй докторській дисертації розкриває роль українського драматичного театру другої половини XIX - початку XX ст. у національнокультурному відродженні. У дисертації Т. Кінзерської (2002) через аналіз творчості видатної актриси українського театру кінця XIX - поч. XX ст. Є. Зарницької досліджено своєрідність сценічного мистецтва корифеїв, що свідчить про існування української мистецької школи, яка виховувала акторів на єдиних творчих засадах.

Натомість для нашого дослідження великого значення набувають наукові праці, які розкривають розвиток сценічного мистецтва саме м. Маріуполя. 
Так, у публікаціях О. Демідко (2014) досліджено виникнення та розвиток сценічного мистецтва в Маріуполі. Доведено, що головним чинником у створенні професійного театру в Маріуполі стає наявність мандрівних труп. Розглянуто діяльність театру в післявоєнні роки. У праці Л. Чуприк (1988) досліджено репертуар Маріупольського театру та гастрольна діяльність колективу. 3 книги спогадів С. Бурова та С. Отченашенко (2003) дізнаємося імена видатних маріупольських акторів та режисерів 1960-х років.

До регіональних досліджень театрального мистецтва м. Маріуполя зараховуємо праці С. Бурова (2003), доробок Л. Яруцького як історико-театрознавчого (1998), так і культурологічно-краєзнавчого характеру (1991). Аналізу творчо-організаційної діяльності Донецького академічного ордена Пошани обласного російського драматичного театру м. Маріуполя в контексті воєнно-історичних подій на Донеччині (1914-1920, 1941-1945, 2014) присвячено дослідження К. Юдової-Романової та А. Безчастної (2015; 2016). Автори аналізують і характеризують основні засади репертуарної та мовної політики театру в окреслені періоди.

Мета статті - розглянути становлення і розвиток театрального мистецтва м. Маріуполя в контексті впливу й відтворення традицій театру корифеїв та їх інтерпретацію в сучасному сценічному мистецтві.

\section{Виклад основного матеріалу}

Актуальність теми обумовлена, по-перше, тим, що на сьогодні маємо хибне уявлення про театр корифеїв, як про такий, що мав у основі натуралістичний показ побуту та етнографії, а манеру акторської гри його діячів вважають занадто театральною, далекою від реалізму. Це зумовило необхідність вивчення його традицій, поєднаних із закордонними традиціями театру, і створення на їх основі нового культурного багатства. По-друге, постійним пошуком нових форм вираження режисерського задуму, а це вимагає наявності синтетичних акторів, які, органічно і майстерно поєднуючи слово, рух, пісню й танець, зможуть його втілити. По-третє, розглядом різних за жанром вистав Донецького академічного обласного драматичного театру (м. Маріуполь), аналізом використання традиційних методів української акторської школи сценічного мистецтва, до яких вдаються постановники в роботі з акторами, та об'єднання їх з більш сучасними доробками світового театру.

З огляду на наукову довідку з історії Донецького академічного обласного драматичного театру м. Маріуполя можемо проаналізувати, як виникало та розвивалося сценічне мистецтво в Маріуполі, що призвело до створення професійного театру в регіоні, яке місце в сучасному мистецтві займають традиції корифеїв (Юдова-Романова та Безчастна, 2016).

Становлення театрального мистецтва Маріуполя є важливим етапом у розвитку мистецьких процесів в Україні. Його початок - 1845 р., коли в Маріуполі з'явився клуб «Маріупольські громадські збори», де проводили бесіди, танці та ігри, організовували читання книжок. 3 приїздом до міста у 1847 р. першої театральної трупи під керівництвом В. Виноградова в амбарі маріупольського купця Н. Попова, який побудував там сцену, партер і місце для оркестру, стали виступати з виставами. 
Імпровізований театр мав назву «Храм музи Мельпомени». У ньому маріупольська публіка мала змогу ознайомитися з творами Миколи Гоголя («Ревізор», «Одруження»), О. Грибоєдова («Лихо з розуму»), О. Островського.

Наприкінці XIX ст. у Маріуполі набуває розвитку й аматорський рух. Розпочинає свою діяльність музично-драматичне товариство, яким керує Е. Батієвський. Його члени влаштовували концерти та ставили аматорські вистави. Після смерті Е. Батієвського товариство очолив І. Ковальський, а режисером став В. Лаптєв. Репертуар складався з таких вистав, як «Без вини винуваті», «Остання жертва», «Фатальний крок», «Хто в ліс, хто по дрова» тощо.

У 1887 році створено стаціонарний театр на 800 місць, що отримав назву Концертний зал, а пізніше - Зимовий театр, під керівництвом В. Кечеджи-Шаповалова. Відкрила сезон прем'єра п'єси «Ревізор» Миколи Гоголя.

Театральні вистави також влаштовували в концертному залі готелю «Континенталь», у театрі Олександрівського парку, у Народному домі на заводі «Нікополь». Про активність театрального життя в Маріуполі свідчать виступи відомих на той час акторів, зокрема В. Андрєєва-Бурлака, М. Кропивницького, І. Карпенка-Карого, П. Саксаганського, Г. Федотової.

Нескінченні фінансові труднощі змусили хазяїна Концертного залу продати його господарю чавуноливарного заводу І. Уварову, який у свою чергу віддав театр в експлуатацію приїжджим антрепренерам. Проте внесок засновника стаціонарних форм театральної діяльності В. Шаповалова $€$ неоціненним. Його відкриттям стала актриса Л. Ліницька, яка мала величезний успіх у п'єсах «Наталка-Полтавка», «Назар Стодоля», «Невольник», «Шельменко-денщик», «Сватання на Гончарівці». У 1889 році Л. Ліницьку запросили до трупи М. Кропивницького.

Динаміка гастрольної діяльності зростає на початку XX ст. На маріупольській сцені виступає відомий російський актор Павло Орленєв, який робить режисерські спроби осучаснити традиційний репертуар за допомогою п'єс Максима Горького. Маріупольські глядачі мали можливість ознайомитися з ними в 1903 році.

у 1906 р. до Маріуполя приїхали солісти Большого театру (Наталі ЄрмоленкоЮжина та Давид Южин) з такими російськомовними виставами, як «Тоска», «Фауст», «Євгеній Онєгін», «Вертер», «Пікова дама».

Під керівництвом І. Уварова в Маріуполі розпочалися гастролі Харківської фарсово-опереткової трупи дирекції Б. Бродерова на чолі з режисером Ф. Шостатським з оперетами «Таємниці нашого міста» В. Валентинова і «Граф Люксембург» Ф. Легара; гастролі алжирської актриси Галіми з виступами імітації інструментальної музики та вокальними номерами; трупи імператорського театру з Токіо з виставою «Прислуга Отаке»; московської опери під керівництвом В. Канєвського з операми «Русалка» та «Борис Годунов»; а також Київської опери з виставами «Травіата» та «Пікова дама».

Отже, гастрольні тури приїжджих труп ознайомили маріупольських глядачів з творчістю артистів різних театральних напрямів, що сприяло збагаченню досвіду місцевих художніх еліт.

У 20-ті роки XX століття соціально-політичні умови не сприяли розвитку сценічного мистецтва в Маріуполі. I хоча театр опинився без фінансової підтримки, 
Вісник Київського національного університету культури і мистецтв.

Серія: Сценічне мистецтво

він продовжував працювати над класичним репертуаром, зокрема над п'єсами В. Шекспіра.

Відсутність придатного приміщення (руйнація будівлі Зимового театру) сприяла розвитку самодіяльних драматичних гуртків, в які входили робітники та службовці. Так, у 1930 р. на базі заводу «Азовсталь» відкрито клуб з драматичним гуртком і самодіяльний театр у клубі ім. К. Маркса.

У 1934 році з метою пропагандистської роботи та відпочинку військовослужбовців у Маріуполі створено професійний Вседонецький музично-драматичний театр, де ставили такі вистави, як «Отелло» В. Шекспіра, «Безприданниця» О. Островського, «Анна Кареніна» Л. Толстого, «Любов Ярова» К. Треньова, «Шторм» В. БілльБілоцерківського. Театр гастролював у таких містах, як Сталіно (Донецьк), Макіївка, Полтава, Кременчук, Суми та Харків. Згодом театр перейменували на Маріупольський музично-драматичний театр ім. Т. Шевченка.

Досвід роботи у різних театральних постановках, який здобули маріупольські актори, став підґрунтям для формування власної школи сценічної майстерності. Сприяв цьому процесу директор театру Андрій Авраменко, представник акторської та режисерської школи Леся Курбаса (Василька ред., 1969). Під його керівництвом розпочала працювати плеяда талановитих режисерів, зокрема І. Тяк, С. Зав'ялова, В. Волгрик.

Вистави виконували переважно українською мовою. Вони в основному складалися з народно-побутових вистав, серед яких були: «Наталка-Полтавка», «Сватання на Гончарівці», «Пошились у дурні», «Наймичка», «Маруся Богуславка», «Ревізор», «Безприданниця», «Вій», «Біда від ніжного серця» тощо. Проводили також вечори пам'яті українських поетів, композиторів і письменників.

Після звільнення Маріуполя від німецьких окупантів українські театральні традиції були частково забуті. У місті почав працювати Державний театр російської драми, репертуарну політику якого визначав А. Ходирєв, котрий у роки війни працював у Борисоглібському драматичному театрі ім. М. Чернишевського. Відповідно до такої політики формувався й акторський склад. Л. Радіонова як провідна актриса театру запам'яталась у таких головних ролях: Лариси в «Безприданниці» О. Островського, Любові Ярової за однойменною п'єсою К. Треньова, жінкикомісара в «Оптимістичній трагедії» В. Вишневського.

У 40-ві роки Маріупольський театр, як і всі інші театри України, працює за стандартами, встановленими комуністичною ідеологією, а саме за принципами соціалістичного реалізму, що не сприяло розвитку сценічної творчості, її зорієнтованості на регіональні потреби. Дирекція театру, дбаючи про виконання планових показників, організовує створення виїзних варіантів постановок для обслуговування населення регіону.

у 1946 р. на сцені Маріупольського державного драматичного театру ставили переважно російську та радянську класику. У репертуарі - «Іванов» А. Чехова, «Так і буде» К. Симонова, «Маскарад» М. Лермонтова, «Анна Кареніна» Л. Толстого.

Крім традиційних для російських театрів творів, тогочасне керівництво доповнювало репертуарну політику творами «на запит дня». Серед них нові вистави «Хліб наш насущний» і «Молода гвардія». Проте успіху вони не мали насамперед 
Bulletin of Kyiv National University of Culture and Arts

Series in Stage Art

через відсутність необхідного театрального реквізиту. Так, для вистави «Молода гвардія» актори брали форму у військових, які, доки йшло сценічне видовище, дивилися спектакль за лаштунками.

Оскільки Маріуполь не був обласним центром та за радянськими нормами міського господарювання не мав права на свою постійну театральну трупу, у 1949 році театр остаточно припиняє свою діяльність. Театральне життя міста представляють гастролюючи театри та колективи художньої самодіяльності.

Проте маріупольців не полишала думка мати свій професійний театр. I тільки в 1959 р. відновлюється діяльність драматичного театру під назвою Донецький російський драматичний театр (м. Маріуполь). Колектив сформовано за допомогою об'єднання акторських труп Кіровоградського та Єнакіївського театру. Трупа поповнилася новими акторами, серед яких заслужені артисти УРСР: А. Коженовська, Є. Вєтрова, М. Кисельова, Ю. Кужелєв, А. Губський, Є. Позднякова, Н. Клепак (Добрунов, 2007, с.4). Директором театру стає В. Раввінов, а головним режисером - народний артист УРСР П. Вєтров.

2 листопада 1960 року відбулося урочисте відкриття театру. Незважаючи на переважну більшість в репертуарі російських драматичних творів, актуальних для тогочасної сцени, нова режисерська генерація все частіше звертається до традиційних для театру корифеїв музичних жанрів. Початок цього процесу наприкінці 60-х років заклав О. Утеганов, учень видатного майстра українського театру М. Крушельницького. Його режисура створила основи піднесено-романтичного стилю прочитання драматичного твору (Чуприк, 1988, с.28).

О. Утеганов спробував відродити українські традиції корифеїв не тільки в режисерських технологіях. Використовуючи у своїй роботі досвід П. Саксаганського, він активно застосовував його методи в роботі акторів над роллю, шукав яскраві барви, глибинні психологічні мотивування кожного образу, спонукав залученого у виставу актора індивідуально мислити щодо вибору засобів вираження, фантазувати. Він також відродив традиції виховання акторів синкретичного плану, для яких спів, слово, дія, танець $€$ спорідненими засобами виразності. Усе це стало підґрунтям для повернення в театр музично-драматичної вистави. Яскравий приклад - вистава «Ніч перед Різдвом» Миколи Гоголя (у постановці режисера А. Левченка), яку поставлено за традиціями українського вертепу. Найтаємничіша сцена у виставі - це обряд з рушниками, який у формі танцю колядників розповідає про славне народження Сина Божого.

Застосовуючи традиції театру корифеїв, обрядову стилістику використала у виставі «Мокошева колисанка» і режисерка Євдокія Тихонова. Головним символом Мокоші було веретено, за допомогою якого вона як давала, так і забирала життя. Прядіння пов'язано з долею, жіночою плодючістю та родючістю. Особливе враження у виставі справляє сцена із зав'язуванням на вузол рушників, які символічно уособлюють позбавлення надії на материнство. Отож, можна стверджувати про використання в режисурі театру нової образно-метафоричної мови.

Джерелом, яке спонукає режисерів Маріупольського театру звернутися до традицій театру корифеїв, стала творчість Т. Шевченка. Цю тенденцію відстежуємо у сценічно-режисерських версіях С. Мусієнка та А. Левченка (вистава «Гайдама- 
ки»). Взаємодія персонажів у різних епізодах тримає глядача в постійній напрузі. Кульмінаційні моменти вистави змінюються на контрастах: від весільних гулянь до кровавих убивств.

Більш традиційною є інтерпретація «Енеїди» режисера А. Левченка за твором І. Котляревського. Хоча в постановці збережено оригінальну мову твору, палітра постановочних елементів дає змогу посилити у виставі натяки на сучасні акценти інтерпретації. Так, козаки та дівчата танцюють під клубну музику, співають пісні, хлопці використовують маорійський ритуальний танець - хака, а образ Ацеста пародіює завсідників «качалок».

Серед останніх робіт Маріупольського театру критики визначили виставу «Шинкарка» С. Новицької, режисер - Д. Попов. У відгуках високу оцінку отримала майстерна гра актриси Олени Білої, а також окремі режисерські знахідки, за допомогою яких вдалося відтворити атмосферу сільського шинку, де відбувається дія усієї вистави. Д. Попов обладнав тин розсувними дошками, які слугували в шинку стіною, а також і буденним простором потойбічної нечисті (відьом, злих духів тощо).

Спектакль «За двома зайцями» М. Старицького на маріупольській сцені відтворила режисерка театру А. Добрунова. У виставі показано народні гуляння парубків і дівчат, а також обряд вінчання Голохвостого та Галі. Роль батька Проні зіграв заслужений актор А. Шевченко (Прокіп Свиридович), а Явдокію Пилипівну - народна артистка України С. Отченашенко. Для створення своїх образів актори за основу брали життя простого люду, манеру поведінки, розмов та звичаїв. Глядачі високо оцінили музичне оформлення вистави, гумористичні пісні, яскраву сценографію і талановиту гру акторів.

Як згадували раніше, з появою в театрі оркестру режисери ввели у вистави живий музичний супровід. Так, дотримуючись традицій корифеїв, у Маріупольському театрі поставлено виставу «Мати» за твором О. Довженка. Це музично-літературна композиція, яку виконують під супровід оркестру «Ренесанс». Жива музика розділяє уривки літературного твору О. Довженка, які виконує С. Отченашенко. Народна артистка України виступає в ролі оповідачки, котра розповідає глядачу про подвиги простої української жінки Марії Стоян, яка пожертвувала собою заради чужих дітей.

Зростання у виставах фольклорно-обрядових елементів сприяло формуванню в діяльності Маріупольського театру нового напряму. Уже кілька років поспіль дуже популярними є театралізовані видовища для дітей, присвячені Дню Святого Миколая та Різдвяним святам, де діти навчаються співати колядки та знайомляться з давніми українськими традиціями.

Наукова новизна дослідження полягає в тому, що виявлено специфіку сучасного акторського мистецтва у Донецькому академічному обласному драматичному театрі (м. Маріуполь) та його зв'язок зі здобутками класичного українського театру корифеїв.

\section{Висновки}

Зважаючи на вищезазначене, маємо підстави твердити, що Донецький академічний обласний драматичний театр (м. Маріуполь) є вагомим осередком 
театральної культури Донеччини. Аналіз діяльності театру на різних етапах його розвитку дає змогу зробити такі висновки:

- історичні реалії розвитку акторської школи корифеїв на Донеччині мають фрагментарне висвітлення в історико-культурологічній, мистецтвознавчій та театрознавчій літературі;

- формування репертуарних уподобань в акторських трупах відбувалося під впливом гастрольної діяльності театру корифеїв. Особливу роль у цьому процесі відігравали принципи роботи над художніми образами як центральним елементом вистави, який її композиційно об'єднує та опосередковано впливає на інші складники;

- незважаючи на період так званого «застою», у театральних практиках радянської доби наприкінці 70-х років простежуємо тенденції повернення до традиційних для українського театру форм сценічної виразності, що сприяло активізації режисерської й акторської творчості в пошуку нових варіантів поєднання театральних засобів української побутової драми з іншими, притаманними класичному та сучасному європейському театру драми та комедії;

- основні риси української акторської школи Маріупольського театру: реалістичний підхід до створення сценічних образів; широке використання музики, співу, танцю; плідна робота актора над собою.

\section{СПИСОК ПОСИЛАНЬ}

Антонович, Д., 2003. Триста років українського театру 1619-1919 та інші праці. Київ: ВІП. Буров, С. и Отченашенко, С., 2003. Из истории Мариупольского театра : годы, события, имена. Мариуполь: Приазовский рабочий.

Василька, В.С. ред., 1969. Лесь Курбас: спогади сучасників. Київ: Мистецтво.

Гордєєв, С.І., 2003. Валентина Чистякова - легенда української сцени. 2-е вид. Харків: Харківська державна академія культури.

Демідко, О.О., 2014. Особливості формування театральної культури Маріуполя у 20-30-ті pp. XX ст. Вісник Маріупольського державного університету. Серія: Філософія, культурологія, соціологія, [online] 7, с.65-69. Доступно: <http://nbuv.gov.ua/UJRN/Vmdu_fks_2014_7_10> [Дата звернення 15 лютого 2020].

Добрунов, К., 2007. Мариупольский драмтеатр стал академическим. Интервьюировано Т. Коваль. Приазовский рабочий. 23 ноября 2007 года, с.4.

Дурылин, С.Н., 1982. Мария Заньковецкая, 1860-1934. Жизнь и творчество. Киев: Мистецтво.

Єсипенко, Р.М., 1994. Роль українського театру у формуванні суспільної свідомості народу в 60-80 роки (на матеріалах драматургії країн близького зарубіжжя). Доктор наук. Київський державний інститут культури.

Заболотна, В., 2006. Театральна Україна в полудень віку: український драматичний театр 40-60-х років XX ст. В: Нариси з історії театрального мистецтва України XX століття. Київ: Інтертехнологія, с.533-586.

Кисіль, О.Г., 1925. Український театр : популярний нарис історії українського театру. Київ: Книгоспілка. 
Кінзерська, Т.П., 2002. Єфросинія Зарницька в українському театральному мистецтві кінця 19-першої половини 20 ст. Автореферат дисертації кандидата наук. Інститут мистецтвознавства, фольклористики та етнології ім. М.Т. Рильського НАН України.

Малюшицька, Н.В., 2002. Системний підхід в театральному мистецтві на прикладі творчості Леся Курбаса. Наука і освіта, 1, с.19-22.

Мар'яненко, І., 1954. Минуле українського театру: Спогади. Київ: Мистецтво.

Новиков, А.О., 2000. Марко Кропивницький і Харківщина : Розвідки, гіпотези, документи. Харків: Майдан.

Тобілевич, С.В., 1947. Корифеї українського театру. Київ: Мистецтво.

Чуприк, Л.Н., 1988. Научная справка из истории Мариупольского театра. Мариуполь: Архив Мариупольского краеведческого музея.

Юдова-Романова, К. та Безчастна, А., 2015. Маріупольський драматичний театр. Віхи становлення. Народознавчі зошити, [online] 5 (125), с.1191-1201. Доступно: <https://nz.lviv. ua/archiv/2015-5/21.pdf> [Дата звернення 15 лютого 2020].

Юдова-Романова, К. та Безчастна, А., 2016. Творчо-організаційна діяльність Донецького академічного ордена Пошани обласного російського драматичного театру м. Маріуполь у періоди воєнних дій. Науковий вісник Київського національного університету театру, кіно і телебачення імені І. К. Карпенка-Карого, [online] 18, c.43-50. Доступно: <http://nbuv.gov.ua/ UJRN/Nvkkarogo_2016_18_8> [Дата звернення 15 лютого 2020].

Яруцкий, Л., 1991. Мариупольская старина : рассказы краеведа. Москва: Советский писатель.

Яруцкий, Л., 1991. Пушкин в Приазовье : литературно-краеведческий очерк. Мариуполь.

Яруцкий, Л., 1998. Старейший в Украине: из истории Донецкого областного драматического театра (г. Мариуполь). Мариуполь: Приазовский рабочий.

\section{REFERENCES}

Antonovych, D., 2003. Trysta rokiv ukrainskoho teatru. 1619-1919 ta inshi pratsi [Three hundred years of Ukrainian theater. 1619-1919 and other works]. Kyiv: VIP.

Burov, S. and Otchenashenko, S., 2003. Iz istorii Mariupolskogo teatra : gody, sobytiia, imena [From the history of the Mariupol Theater: years, events, names]. Mariupol: Priazovskii rabochii. Chuprik, L.N., 1988. Nauchnaia spravka iz istorii Mariupolskogo teatra [Scientific reference from the history of the Mariupol Theater]. Mariupol: Arkhiv Mariupolskogo kraevedcheskogo muzeia. Demydko, O.O., 2014. Osoblyvosti formuvannia teatralnoi kultury Mariupolia u 20-30-ti rr. XX st. [Features of formation of Mariupol's theatrical culture in the 20-30's of the XX century]. Visnyk Mariupolskoho derzhavnoho universytetu. Seriia: Filosofiia, kulturolohiia, sotsiolohiia, [online] 7, pp.65-69. Available at: <http://nbuv.gov.ua/UJRN/Vmdu_fks_2014_7_10> [Accessed 15 February 2020].

Dobrunov, K., 2007. Mariupolskii dramteatr stal akademicheskim [The Mariupol Drama Theater has become academic]. Interviuirovano T. Koval. Priazovskii rabochii. 23 November 2007, p.4.

Durylin, S.N., 1982. Mariia Zankovetckaia, 1860-1934. Zhizn i tvorchestvo [Maria Zankovetskaya, 1860-1934. Life and creation]. Kyiv: Mistetctvo.

Hordieiev, S.I., 2003. Valentyna Chystiakova - lehenda ukrainskoi stseny [Valentina Chistyakova is a legend of the Ukrainian scene]. $2^{\text {nd }}$ edn. Kharkiv: Kharkivska derzhavna akademiia kultury. larutckii, L., 1991. Mariupolskaia starina : rasskazy kraeveda [Mariupol antiquity: stories of the local historian]. Moscow: Sovetskii pisatel. 
larutckii, L., 1991. Pushkin v Priazove : literaturno-kraevedcheskii ocherk [Pushkin in the Azov region: literary and local history essay]. Mariupol.

larutckii, L., 1998. Stareishii v Ukraine: iz istorii Donetckogo oblastnogo dramaticheskogo teatra (g. Mariupol) [The oldest in Ukraine: from the history of the Donetsk Regional Drama Theater (Mariupol)]. Mariupol: Priazovskii rabochii.

lesypenko, R.M., 1994. Rol ukrainskoho teatru u formuvanni suspilnoi svidomosti narodu $\checkmark$ 60-80 roky (na materialakh dramaturhii krain blyzkoho zarubizhzhia) [The role of Ukrainian theater in the formation of public consciousness of the people in 60-80 years (based on the materials of the dramaturgy of CIS countries)]. D.Ed. Kyivskyi derzhavnyi instytut kultury.

Kinzerska, T.P., 2002. Yefrosyniia Zarnytska $v$ ukrainskomu teatralnomu mystetstvi kintsia 19-pershoi polovyny 20 st. [Efrosinia Zarnitskaya in Ukrainian theatrical art of the late 19th-first half of the 20th century]. Abstract of the dissertation of the candidate of sciences. Instytut mystetstvoznavstva, folklorystyky ta etnolohii im. M.T. Rylskoho NAN Ukrainy.

Kysil, O.H., 1925. Ukrainskyi teatr : populiarnyi narys istorii ukrainskoho teatru [Ukrainian theater: a popular essay on the history of Ukrainian theate]. Kyiv: Knyhospilka.

Maliushytska, N.V., 2002. Systemnyi pidkhid v teatralnomu mystetstvi na prykladi tvorchosti Lesia Kurbasa [A systematic approach in theatrical art on the example of Les Kurbas's work]. Nauka i osvita, 1, pp.19-22.

Marianenko, I., 1954. Mynule ukrainskoho teatru: Spohady [Past Ukrainian Theater: Memories]. Kyiv: Mystetstvo.

Novykov, A.O., 2000. Marko Kropyvnytskyi i Kharkivshchyna: Rozvidky, hipotezy, dokumenty [Marko Kropyvnytskyi and Kharkiv Region: Intelligence, Hypotheses, Documents]. Kharkiv: Maidan.

Tobilevych, S.V., 1947. Koryfei ukrainskoho teatru [Coryphaeus of Ukrainian theater]. Kyiv: Mystetstvo

Vasylka, V.S. ed., 1969. Les Kurbas: spohady suchasnykiv [Les Kurbas: Memories of Contemporaries]. Kyiv: Mystetstvo.

ludova-Romanova, K. and Bezchastna, A., 2015. Mariupolskyi dramatychnyi teatr. Vikhy stanovlennia [Mariupol Drama Theater. Formation Milestones]. Narodoznavchi zoshyty, [online] 5 (125), pp.1191-1201. Available at: <https://nz.lviv.ua/archiv/2015-5/21.pdf> [Accessed 15 February 2020].

ludova-Romanova, K. and Bezchastna, A., 2016. Tvorcho-orhanizatsiina diialnist Donetskoho akademichnoho ordena Poshany oblasnoho rosiiskoho dramatychnoho teatru $\mathrm{m}$. Mariupol u periody voiennykh dii [Creative and organizational activity of the Donetsk Academic Order of Honor of the Regional Russian Drama Theater in Mariupol during the periods of hostilities]. Naukovyi visnyk Kyivskoho natsionalnoho universytetu teatru, kino i telebachennia imeni I. K. KarpenkaKaroho, [online] 18, pp.43-50. Available at: <http://nbuv.gov.ua/UJRN/Nvkkarogo_2016_18_8> [Accessed 15 February 2020].

Zabolotna, V., 2006. Teatralna Ukraina $v$ poluden viku: ukrainskyi dramatychnyi teatr 40-60-kh rokiv XX st. [Theatrical Ukraine at noon: Ukrainian Drama Theater of the 40's and 60's of the XX century]. In: Narysy z istorii teatralnoho mystetstva Ukrainy XX stolittia [Essays on the History of Theater Art of Ukraine of the XX Century]. Kyiv: Intertekhnolohiia, pp.533-586. 


\title{
ТЕАТРАЛЬНОЕ ИСКУССТВО МАРИУПОЛЯ: СТРАНИЦЫ ИСТОРИИ И СОВРЕМЕННЫЕ РЕАЛИИ
}

\author{
Любовь Голубцова ${ }^{1 a}$, Сергей Плуталов²a, Марина Мусиенко ${ }^{3 b}$ \\ ${ }^{1}$ кандидат искусствоведения, доцент; e-mail: golubtsova@i.ua; ORCID: 0000-0002-5807-2176 \\ ${ }^{2}$ магистр; e-mail: si.plutalovv@gmail.com; ORCID: 0000-0001-9155-5324 \\ ${ }^{3}$ магистр; e-mail: m.musienko0511@yandex.ua; ORCID: 0000-0002-8928-3785 \\ а Луганская государственная академия культуры и искусств, Киев, Украина

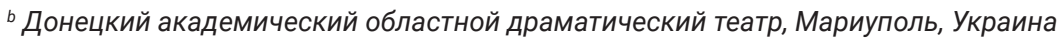

\section{Аннотация}

Цель исследования - рассмотреть историю возникновения сценического искусства Мариуполя и охарактеризовать технологии актерского искусства (традиционные и инновационные), на которые опирается в своей деятельности коллектив Мариупольского драматического театра. Методология исследования. Для достижения цели исследования использованы следующие методы: исторический (для исследования этапов становления театрального искусства Донбасса); аналитический (с целью выявления основных принципов актерской школы как результата ее исторической эволюции); культурологический (для рассмотрения традиций актерской школы в контексте развития современного сценического искусства Мариуполя); искусствоведческий (в анализе актерской школы и форм режиссерских технологий); источниковедческих (в изучении архивных материалов, связанных с театральной жизнью города). Научная новизна заключается в том, что выявлена специфика современного актерского искусства Мариуполя, а также его связи с достижениями классического украинского театра корифеев. Выводы. Центром театральной культуры Донецкого региона является Донецкий академический областной драматический театр (г. Мариуполь). Анализ деятельности театра на разных этапах его функционирования позволяет утверждать, что исторические реалии развития актерской школы корифеев в Донецкой области нашли фрагментарное отражение в историкокультурологической, искусствоведческой и театроведческой литературе; формирование репертуарных предпочтений в актерских труппах происходило под влиянием гастрольной деятельности театра корифеев. Особую роль в этом процессе играли принципы работы над художественными образами как центральным элементом спектакля, который его композиционно объединяет и косвенно влияет на другие составляющие. Несмотря на период так называемого «застоя», в советских театральных практиках в конце 70-х годов прослеживаются тенденции возвращения к традиционным для украинского театра форм сценической выразительности, что способствовало активизации режиссерского и актерского творчества в поиске новых вариантов сочетания театральных средств украинской бытовой драмы с другими, присущими классическому и современному европейскому театру драмы и комедии. Основные черты украинской актерской школы Мариупольского театра: реалистичный подход к созданию сценических образов; широкое использование музыки, пения, танца; плодотворная работа актера над собой.

Ключевые слова: сценическое искусство Мариуполя; актерское искусство; традиции театра корифеев 


\title{
THE THEATER ART OF MARIUPOL: PAGES OF HISTORY AND MODERN REALITIES
}

\author{
Liubov Golubtsova1a, Serhii Plutalov²a, Maryna Musienko ${ }^{3 b}$ \\ ${ }^{1}$ Ph.D. in Arts, Associate Professor; e-mail: golubtsova@i.ua; ORCID: 0000-0002-5807-2176 \\ ${ }^{2}$ master; e-mail: si.plutalovv@gmail.com; ORCID: 0000-0001-9155-5324 \\ ${ }^{3}$ master; e-mail: m.musienko0511@yandex.ua; ORCID: 0000-0002-8928-3785 \\ ${ }^{a}$ Lugansk State Academy of Culture and Arts, Kyiv, Ukraine \\ ${ }^{b}$ Donetsk Academic Regional Drama Theater, Mariupol, Ukraine
}

\begin{abstract}
The purpose of the research is to review the history of Mariupol's performing arts and to characterize the acting arts technologies (traditional and innovative), which the staff of the Mariupol Drama Theater relies on in its activity. Research methodology. The following methods have been used to achieve the goal of the research: historical is (to study the stages of the theatrical art formation of Donetsk region); analytical is (to identify the basic principles of the acting school as a result of its historical evolution); cultural studies is (to consider the acting school traditions in the context of the contemporary performing arts development in Mariupol); art studies is (in the analysis of acting schools and forms of directing technologies); source studies is (in the study of archival materials related to the theatrical life of the city). The scientific novelty is that the peculiarities of Mariupol contemporary acting art and its relation to the achievements of classical Ukrainian theater of luminaries have been revealed. Conclusions. The center of Donetsk region's theatrical culture is the Donetsk Academic Regional Drama Theater (Mariupol). The analysis of the theater activity at different stages of its functioning makes it possible to confirm that the historical realities of the acting school development of luminaries in Donetsk have fragmentary coverage in the historical, cultural, art and theatrical literature; the formation of repertoire preferences in the actors' troupes was influenced by the touring activities of the Coryphaeus Theater. A special role in this process was played over the principles of artistic images as a central element of the performance, which combines its composition and indirectly affect other components. Despite the period of the so-called "stagnation", in the Soviet theatrical practices in the late 70's we trace the tendency to return to the traditional forms of theatrical expressiveness for the Ukrainian theater, which helped to activate the directing and acting creativity in search of new variants of combining theatrical means of the Ukrainian everyday life inherent in classical and contemporary European drama and comedy theater. The main features of the Ukrainian Acting School of the Mariupol Theater are realistic approach to the creation of stage images; widespread use of music, singing, dance; the productive work of the actor over himself.
\end{abstract}

Keywords: Mariupol Performing Arts; acting; traditions of the theater of luminaries 